\title{
The Use of Animal Models to Dissect the Biology of Leptin
}

\author{
Farid F. Chehab, Jun Qiu, and Scott Ogus \\ Department of Laboratory Medicine, University of California, San Francisco, \\ California 94143-0134
}

\begin{abstract}
Our understanding of the effects of leptin have stemmed mainly from animal studies, which continue to leave important clues of its roles in physiology, metabolism, neuroscience, and cell signaling. Since its discovery, leptin has been linked to various pathways, either directly at its primary site of action in the hypothalamus, or indirectly via downstream effector pathways such as in adipocytes and muscle. Leptin's importance is exemplified by the lack of redundant backup mechanisms, since leptin-deficient mice are obese, diabetic, and sterile. Investigations uncovering the pleiotropic actions of leptin were unfolded mainly from rodent models. Thus, this chapter focuses on these studies and, more specifically, on those findings recently brought forward by transgenic mice overexpressing leptin. The vast amount of biology that has been ascribed to leptin encompasses effects on food intake, insulin sensitivity, adiposity, thermogenesis, reproduction, immunity, and bone regulation. Mechanisms underlying leptin's action revolve essentially around neural pathways but also encompass to a lesser extent peripheral mechanisms. The roles of leptin along these axes are reviewed, with particular emphasis on pathways and phenotypes generated by transgenic hyperleptinemia. An evolutionary significance of hyperleptinemia in association with development of leptin resistance is suggested as a protective armament against some of the detrimental effects caused by hyperleptinemia in transgenic mice overexpressing leptin.
\end{abstract}

\section{Introduction}

The discovery of the adipocyte-derived hormone leptin (Zhang et al., 1994) opened a new field of investigation, heightened interest in dissecting pathways regulating energy homeostasis, and a fresh viewpoint on treating obesity and associated disorders such as diabetes, syndrome $\mathrm{X}$, polycystic ovary syndrome, and hypertension. It has long been known that obesity exacerbates these conditions; thus, the discovery of leptin replaced the interest brought earlier by adipsin (Flier et al., 1987) and tumor necrosis factor (TNF) alpha (Hotamisligil et al., 1993), by providing a new entry point to delineate mechanisms of energy homeostasis. Preparation of recombinant leptin allowed its exogenous effects to be tested on normal and leptin-deficient ob/ob mice (Campfield et al., 1995; Halaas et al., 1995; Pelleymounter et al., 1995; Weigle et al., 1995). The major outcomes from these early studies showed a significant decrease in food intake, 
increase in energy expenditure, and selective attenuation of the adipose fat mass. Another major effect of leptin was on the reproductive axis (Chehab et al., 1996), which is directly linked to an organism's nutritional status. It was shown that leptin treatment of ob/ob mice could rescue their lifelong sterility, while, in normal mice, it could suppress fasting-induced anestrous (Ahima et al., 1996) and stimulate the onset of puberty (Ahima et al., 1997; Chehab et al., 1997; Yura et al., 2000). Other functions of leptin were associated with immunity (Lord et al., 1998) and a central regulation of bone formation (Ducy et al., 2000; Takeda et al., 2002). The failure of exogenous leptin treatment to attenuate the obesity in other animal models of obesity — such as the $d b / d b$ mouse, the agouti yellow mouse, and the melanocortin 4 receptor (MC4-R) null mouse (Huszar et al., 1997), which all are associated with elevated leptin levels - gave rise to the concept of leptin resistance and hyperleptinemia, a condition reflected in most forms of human obesity (Considine et al., 1996). All these findings suggested that leptin has multiple roles beyond its body weight-thinning effects, as initially suggested by its name (Flier, 1998). Thus, to study leptin's systemic and chronic effects and to delineate mechanisms of action, transgenic animal models of leptin overexpression are warranted. This review is aimed mainly at pinpointing the most-relevant aspects of leptin biology that have and could emerge from overexpressing leptin in the mouse.

\section{Animal Models of Leptin Overexpression}

To date, there have been reports of four transgenic mouse models overexpressing leptin. One model resulted from leptin overexpression at very high levels under control of the liver-specific albumin promoter (Ogawa et al., 1999). Two additional models used the fatty acid binding protein aP2 promoter to direct expression of leptin specifically to adipocytes, resulting in, in one case, moderately elevated leptin levels (Qiu et al., 2001b) and in the other, very low leptin levels (Ioffe et al., 1998). A fourth model directed leptin expression to the osteoblast using the alpha-1 collagen promoter (Takeda et al., 2002). Although the low aP2-expressing line and the osteoblast line did not significantly alter circulating levels of leptin, they addressed specific questions regarding the sensitivity of $o b / o b$ mice to small amounts of leptin and local effects on bone formation, respectively. Overexpression of leptin in a rat model also was generated using an adenoviral vector (Chen et al., 1996). This review mainly addresses studies that emerged from the high and moderately elevated leptinoverexpressing lines (referred herein as LepTg) and the rat model, all of which investigated metabolic and broader effects of leptin.

\section{Food Intake}

Exogenous administration of leptin to $o b / o b$ mice resulted in dose-dependent reductions in food intake (Pelleymounter et al., 1995), with the greatest inhibition 
occurring during the early phases of leptin treatment. This demonstrated the exquisite sensitivity of $o b / o b$ mice to leptin. In normal mice, large leptin doses were required to result in a $35 \%$ reduction of food intake, which eventually stabilized to match the food intake of nonleptin-treated normal mice (Halaas et al., 1995). These studies demonstrate that normal mice respond to leptin treatment and adapt to its anorectic effects. In LepTg mice overexpressing 12 -fold and 8-fold leptin, reductions in food intake were $25 \%$ and $15 \%$, respectively (Ogawa et al., 1999; Qiu et al., 2001b). This once again demonstrated the dose-dependent effect but, interestingly, the lack of adaptation to anorectic effects of leptin. Adult rats infected with an adenoviral leptin construct resulted in a 10-fold hyperleptinemia and a $30-50 \%$ reduction in food intake (Chen et al., 1998). These decreases in food intake are likely to represent near-maximal levels of tolerance that a mouse can sustain without suffering devastating physiological consequences of a caloric deficit. The implications of this functional hyperleptinemia (as opposed to hyperleptinemia associated with leptin resistance) suggests that while there may be a saturable transport of leptin to the hypothalamus (Banks et al., 1996), normal circulating endogenous leptin levels are far below the threshold required to achieve a transport saturation. Because the 12-fold overexpressing LepTg line resulted in a larger decrease in food intake than the 8-fold overexpressing line, it is reasonable to assume that an 8 -fold leptin overexpression still does not result in transport saturation. Mechanisms leading to chronic reductions of food intake in response to functional hyperleptinemia are likely to involve a continuous downregulation of the orexigenic pathway involving neuropeptide Y (NPY) neurons and activation of the anorectic pathway mediated by pro-opiomelanocortin (POMC) neurons and the melanocortin 4 receptor (MC4R) (Cowley et al., 2001). Thus, steady-state reductions of food intake in normal mice suggest that pharmacological manipulations of MC4R could result in long-term reductions in food intake in individuals who might be responsive to leptin. Overall, the anorectic effects of leptin in an organism susceptible to hyperleptinemia appear to be dose related. While they are more pronounced when exogenously administered for short periods, they last longer when chronically secreted from a transgene. Interestingly, experiments by Coleman and Hummel (1969) involving the parabiotic union of $d b / d b$ mice (overexpressing leptin) with normal mice led to wasting and death of the normal parabiont. In contrast, LepTg mice, while continuously responding to transgenic hyperleptinemia, do not suffer from energy deprivation or a wasting phenotype, suggesting that sensitivity to hyperleptinemia is not detrimental to energy homeostasis. It is to be noted that leptin-mediated anorexia is not associated with the detrimental effects of fasting, which unlike leptin treatment (Wang et al., 1999), result in elevated circulating free fatty acids (FFAs), showing an unusual role for leptin in lipolysis. 


\section{Regulation of Adiposity}

The characteristic and most-prominent feature of exogenous leptin treatment by any means was a decrease in body weight, which was accounted for almost entirely by a reduced adipose tissue mass. In LepTg mice, the extent of this effect correlated with transgenic leptin levels and varied from a small fat mass (Qiu et al., 2001b) to a virtual absence (Chen et al., 1996; Ogawa et al., 1999), reflecting quantitative effects of leptin on the fat mass. When adipose tissue could be recovered, histological analysis revealed that, compared to normal mice, LepTg adipocytes were 4-fold smaller and were either depleted of triacylglycerol stores or contained minute lipid droplets (Qiu et al., 2001b; Ogus et al., 2003). Whether these small cells represent preadipocytes, adipocytes, or a mixture of both remains to be determined. However, mRNA expression of the fatty acid binding protein aP2, which is expressed only in mature adipocytes, failed to reveal any quantitative differences between normal and leptin transgenic mice. This suggests that the majority of these cells consist of mature adipocytes, albeit without visible intracellular lipids. Recovery and growth of these adipocytes in vitro in a medium rich in glucose, insulin, and insulin-like growth factor-1 (IGF-1), which are all significantly decreased in LepTg mice, revealed a rapid accumulation of triacylglycerols, suggesting a heightened sensitivity to lipid accumulation (Ogus et al., 2003).

The histological makeup of the adipose tissue in the leptin-overexpressing mice is not unique to leptin (Figure 1) but rather characteristic of lean mice with small fat masses, such as fasted mice, transgenic mice overexpressing a dominant-positive form of sterol regulatory element-binding protein-1c (SREBP1c) (Shimomura et al., 1998), forkhead box subclass C member 2 (FOXC2) (Cederberg et al., 2001), or knockout (KO) mice for either the type II regulatory subunit of protein kinase A (Cummings et al., 1996), protein tyrosine phosphatase 1B (Elchebly et al., 1999; Klaman et al., 2000), or the lipid-coating protein perilipin (Martinez-Botas et al., 2000; Tansey et al., 2001). Thus, the convergence of different pathways to a common phenotype - namely, the depletion of triacylglycerols from adipocytes - demonstrates the various effectors that impact the adipose mass. The question of whether these molecules belong to a common pathway orchestrated by leptin remains to be answered.

In nonadipose tissues (e.g., liver, muscle), leptin prevents the lipotoxicity associated with triacylglycerol buildup (Lee et al., 2001) by activating 5 '-adenosine monophosphate (AMP)-activated protein kinase (AMPK), which stimulates fatty acid oxidation via inhibition of acetyl coenzyme A carboxylase. Leptin's action on stimulating AMPK activity is mediated chiefly via the central nervous system (CNS), with a moderate peripheral action (Minokoshi et al., 2002). Since triacylglycerol buildup in muscle is associated with insulin resistance, it is conceivable that leptin treatment 

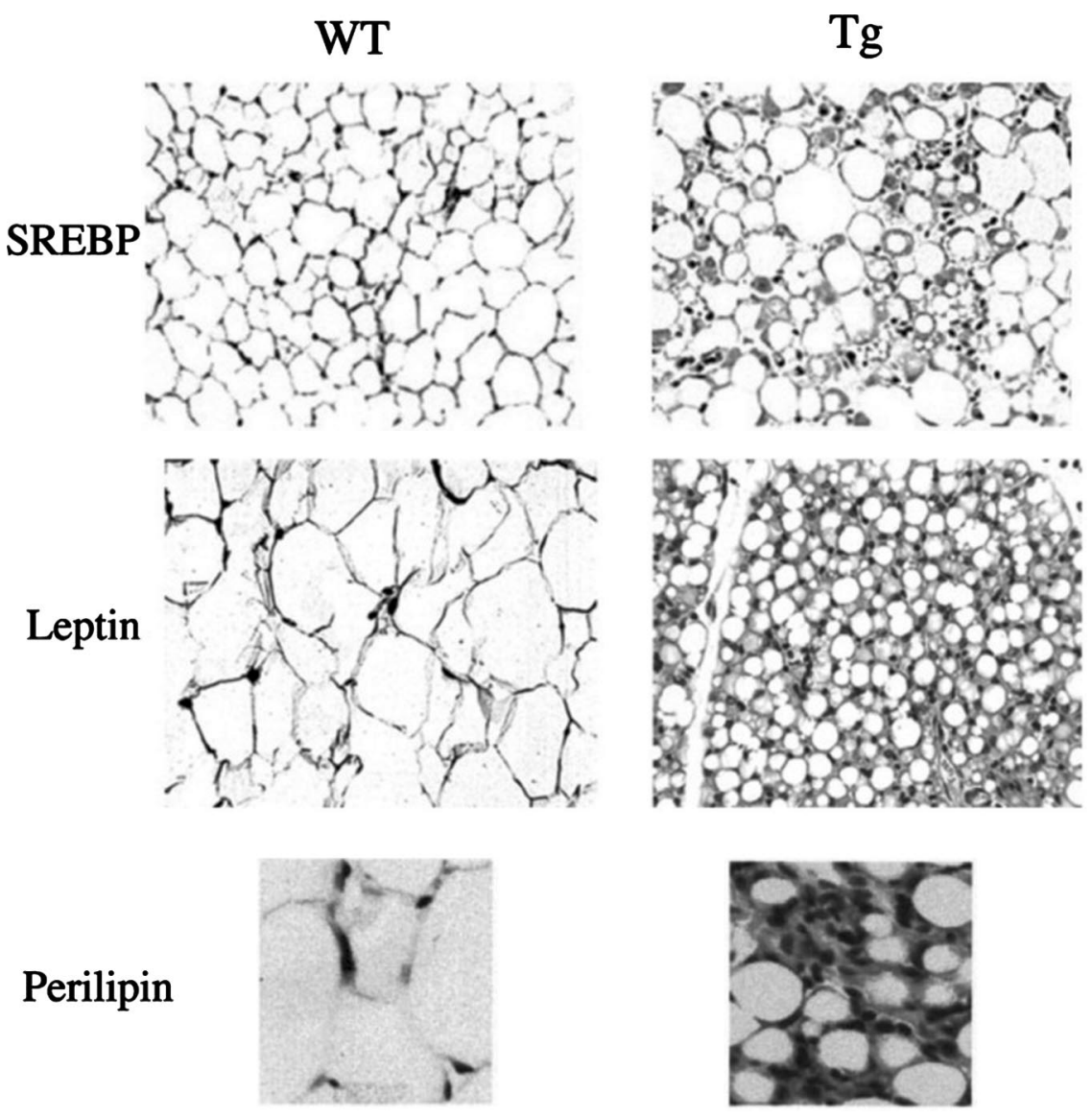

FIG. 1. Histology of white adipose tissue, stained with hematoxylin/eosin (H/E) from normal and lipodystrophic mice overexpressing either sterol regulatory element-binding protein-1c (SREBP1c), leptin, or homozygous for a targeted deletion in perilipin. The extent of lipid accumulation and adipocyte sizes of the transgenic ( $\mathrm{Tg}$ ) mice are greatly reduced, compared to those of wild-type (WT) mice. [Reprinted with permission from Shimomura S, Hammer RE, Richardson JA, Ikemoto S, Bashmakov Y, Goldstein JL, Brown MS 1998 Insulin resistance and diabetes mellitus in transgenic mice expressing nuclear SREBP-1c in adipose tissue: model for congenital generalized lipodystrophy. Genes Dev 12:3182-3194; Qiu J, Ogus S, Lu R, Chehab FF 2001 Transgenic mice overexpressing leptin accumulate adipose mass at an older, but not younger, age. Endocrinology 142:348358. Copyright The Endocrine Society; Tamsey JT, Sztalryd C, Gruia-Gray J, Roush DL, Zee JV, Gavrilova O, Reitman ML, Deng CX, Li C, Kimmel AR, Londos C 2001 Perilipin ablation results in a lean mouse with aberrant adipocyte lipolysis, enhanced leptin production and resistance to diet induced obesity. Proc Natl Acad Sci USA 98:6494-6499. Copyright 2001 National Academy of Sciences, U.S.A.] 
might alleviate this effect by stimulating intramuscular lipolysis, thereby improving the diabetes phenotype.

\section{Adaptation to Cold and Diet-induced Thermogenesis}

Brown adipose tissue (BAT) is greatly affected in LepTg mice. However, in contrast to white adipose tissue, brown adipocytes appeared entirely devoid of triacylglycerol stores, at least as seen by light microscopic analysis (Qiu et al., 2001b), suggesting a dysfunctional hypothalamic-BAT axis. A prominent characteristic of rodents is their adaptation to cold temperatures, a mechanism that ensures their survival in nature. The underlying mechanism for adaptive thermogenesis involves the uncoupling of oxidative phosphorylation to generate heat via increased expression and activity of mitochondrial uncoupling protein 1 (UCP-1) in BAT. Moreover, UCP-1 expression and activity can be stimulated via diet-induced thermogenesis, converting excess calories into heat (Himms-Hagen, 1984) and protecting the animal against obesity to some extent. Leptin's role in thermogenesis is evidenced by the cold intolerance of leptin-deficient and leptin receptor-deficient obese mice and, paradoxically, by leptin-overexpressing lean mice. Indeed, LepTg mice, unlike normal mice, were sensitive to a cold challenge and quickly succumbed to hypothermia if not rescued from the cold. This effect was independent of UCP-1 expression in BAT, since restoration of triacylglycerols in adipose tissue via high-fat diet feeding resulted in normal cold tolerance of the leptin transgenic mice (Qiu et al., 2001b). Therefore, the absence of triacylglycerols in BAT failed to provide substrates for the ability of UCP-1 to uncouple oxidative phosphorylation. On the other end of the spectrum, obese mice deficient in either leptin or leptin signaling are also cold intolerant, despite the massive accumulation of triacylglycerols in BAT (Trayhurn and James, 1978; Trayhurn, 1979). Therefore, leptin plays a primordial role in regulating the hypothalamic-BAT axis. Any interference with its regulation, whether manifested in an excessively lean or obese state, is reflected by a perturbation of thermogenesis. This effect appears to be quantitative and subject to threshold levels of triacylglycerols. For example, unlike LepTg mice, perilipin KO mice could adapt to the cold (Figure 2), despite their reduced fat mass and significantly decreased intracellular triacylglycerols. However, when further depleted of their residual intracellular triacylglycerols by fasting, they could not withstand a cold challenge (Martinez-Botas et al., 2000). Lipoatrophy of the perilipin KO mice is not as severe as that of LepTg mice, which quickly succumb to a cold challenge in the fed state. Thus, regulatory thermogenesis requires the presence of leptin and of a critical intracellular level of triacylglycerols in adipocytes, to elicit the induction of UCP-1 expression and activity, thereby ensuring survival of the animal at low temperatures. 

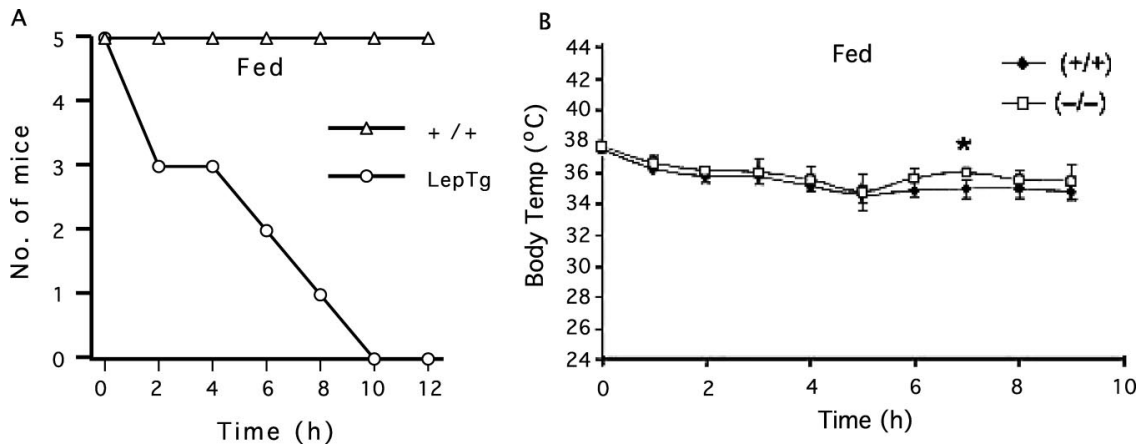

FIG. 2. Differential effects of thermogenesis in lipodystrophy in ad libitum-fed LepTg and perilipin knockout $(\mathrm{KO})$ mice. $(\mathrm{A})$ Number of LepTg mice $(\mathrm{O})$ that did not tolerate the cold, resulting in a significant drop of their body temperature to $17.4^{\circ} \mathrm{C}-25^{\circ} \mathrm{C}$, compared to the stable body temperature of normal mice $(\triangle)$. (B) Perilipin $\mathrm{KO}(-/-)$ were insensitive to the cold and adjusted appropriately, similar to WT controls (+/+). [(B) Reprinted with permission from Martinez-Botas J, Anderson JB, Tessier D, Lapillonne A, Chang BH, Quast MJ, Gorenstein D, Chen KH, Chan L 2000 Absence of perilipin results in leanness and reverse obesity in Lepr $(d b / d b)$ mice. Nature Genet 26:474-479. Copyright Nature Publishing Group.]

The mechanism by which leptin induces UCP-1 is mainly through the sympathetic nervous system (SNS) (Collins et al., 1996), since central administrations of leptin resulted in increased UCP-1 expression. In addition, the MC4R, a downstream target of leptin, appears to mediate this effect because the leptin-mediated induction of UCP-1 expression could be blocked with SHU9119, a potent antagonist of alpha-melanocyte stimulating hormone ( $\alpha$-MSH) (Satoh et al., 1998). Since $\alpha$-MSH acts as an agonist at the MC4R, one would expect that MC4R KO mice would not tolerate the cold. However, this is not the case. Adult - and therefore obese - MC4R null animals have normal body temperature and tolerate cold well (Ste Marie et al., 2000), suggesting that additional $\alpha$-MSHmediated mechanisms are involved in the SNS response to cold.

\section{Glucose Homeostasis and Insulin Sensitivity}

A hallmark of leptin treatment of $o b / o b$ mice was their improved insulin sensitivity and amelioration of their hyperglycemia independently of effects on food intake (Halaas et al., 1995). Thus, the link between insulin sensitivity, glucose metabolism, and leptin became the focus of intense investigation. Although circulating glucose levels in LepTg mice ranged from normal (Ogawa et al., 1999) to low (Qiu et al., 2001b), plasma levels of insulin, FFAs, and triglycerides were depressed in both transgenic lines. The antidiabetic properties of leptin also were demonstrated in lipoatrophic diabetic mice treated with leptin, 
either exogenously, as with the aP2-nSREBP1c transgenic mice (Shimomura et al., 1998), or by crossing the LepTg mice with the A-ZIP-F1 KO mice (Ebihara et al., 2001) that are lipoatrophic and diabetic (Moitra et al., 1998). Although the mechanisms underlying this leptin-mediated improvement in insulin sensitivity remain to be determined, it is likely that the steatosis associated with lipodystrophy could be ameliorated by leptin. This makes it as a prime candidate for the treatment of lipodystrophies such as in the Berardinelli-Seip syndrome (Berardinelli, 1954; Seip and Trygstad, 1963; Savage and O'Rahilly, 2002).

\section{Reproduction}

While the role of leptin in energy homeostasis was the center of investigation, due mainly to the morbid obesity of leptin-deficient $o b / o b$ mice, their infertility had not caught up with the excitement of leptin's discovery, even though it had been investigated in parabiosis experiments (Lane, 1959) prior to those by Coleman (Coleman and Hummel, 1969). The finding that leptin rescued the sterility of $o b / o b$ mice (Chehab et al., 1996) and advanced the puberty of normal mice (Ahima et al., 1997; Chehab et al., 1997; Yura et al., 2000) carved a place for it in reproductive biology.

It is often assumed - erroneously — that obesity is always associated with hypogonadism and infertility. While this may be correct for the Prader-Willi syndrome (Hamilton et al., 1972) and the rare occurrences of leptin and leptin receptor mutations (Montague et al., 1997; Clement et al., 1998), only 60\% of obese patients with the Bardet-Biedl syndrome exhibit hypogonadism (Jones, 1988). Association studies between nonsyndromic obesity and hypogonadism remain scarce and worthy of investigation.

In animal models, obesity caused by leptin or leptin receptor mutations results in infertility, whereas KO mice at the MC4-R (which is downstream of leptin) are obese and fertile. So what is the role of leptin in reproduction and what is its mechanism of action on the reproductive system? Exogenous leptin treatment of normal mice advanced vaginal opening (Figure 3) by a few days (Ahima et al., 1997; Chehab et al., 1997). However, in ad libitum-fed rats, leptin did not significantly alter the normal course of puberty, although it was able to partially reverse the delay in sexual maturation caused by reduced feeding (Cheung et al., 1997). Studies have shown that intracerebroventricular (ICV) injections of leptin induce prepubertal secretion of luteinizing hormone (LH) (Dearth et al., 2000), whereas leptin antibodies inhibit the leptin-mediated stimulation of LH release (Carro et al., 1997). Transgenic mice oversecreting 12 -fold excess leptin showed early vaginal opening (Yura et al., 2000) but those with 8-fold overexpression did not (F.F. Chehab, unpublished observations). Thus, for leptin to significantly impact the onset of puberty and the firing of the reproductive system, elevated leptin levels analogous to the prepubertal leptin 


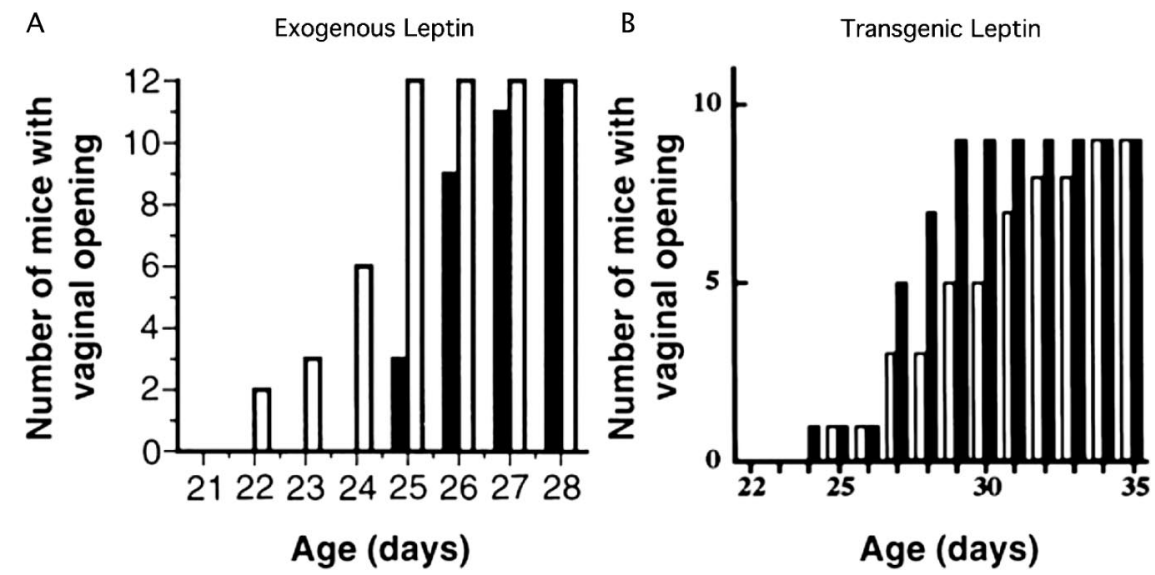

FIG. 3. Stimulation of puberty by exogenous leptin treatment or transgenic hyperleptinemia. Leptin treatment of prepubertal normal mice resulted in earlier vaginal opening (A), similar to LepTg mice (B), demonstrating a stimulatory effect on the reproductive system. [(A) Reprinted with permission from Chehab FF, Mounzih K, Lu R, Lim ME 1997 Early onset of reproductive function in normal female mice treated with leptin. Science 275:88-90. Copyright The American Association for the Advancement of Science; (B) from Yura S, Ogawa Y, Sagawa N, Masuzaki H, Itoh H, Ebihara K, Aizawa-Abe M, Fujii S, Nakao K 2000 Accelerated puberty and late-onset hypothalamic hypogonadism in female transgenic skinny mice overexpressing leptin. J Clin Invest 105:749-755.]

spike found in mice (Ahima et al., 1998) and rats (Nagatani et al., 2000) may be required. In the former case, this preceded the appearance of estradiol but coincided with that of insulin (Figure 4), suggesting an indirect stimulation of estradiol secretion and a concomitant action with insulin. Furthermore, the presence of a transgene overexpressing small amounts of leptin onto the $o b / o b$ background rescued only the infertility of the phenotype, without affecting obesity (Ioffe et al., 1998), demonstrating the exquisite sensitivity of the reproductive system to leptin. Similarly, human studies have shown that leptindeficient patients who fail to enter puberty naturally progress through puberty with leptin treatment (Farooqi et al., 1999). Paradoxically, in rhesus monkeys, associations between prepubertal leptin rise and the onset of puberty were lacking in one study (Plant and Durrant, 1997) but were evident in another using a different leptin-sampling paradigm (Suter et al., 2000). Nevertheless, exogenous leptin treatment of rhesus monkeys did not appear to elicit precocious puberty, which could be attributed to the fact that the monkeys had developed leptin antibodies (Barker-Gibb et al., 2002).

The role of leptin as a conveyor of energy stores to the reproductive system is logical. While studies have concentrated on the fact that leptin may perform this function single-handedly, the complexity of the mammalian system and the 
A

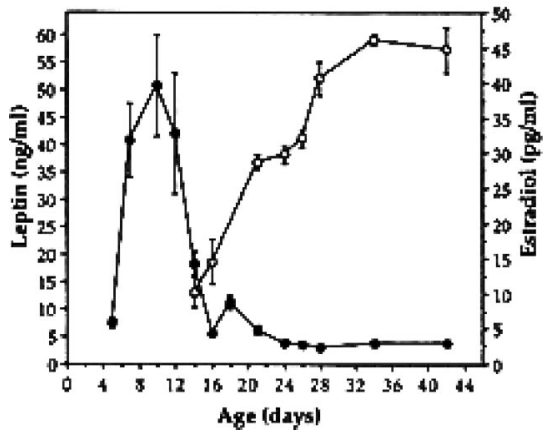

B

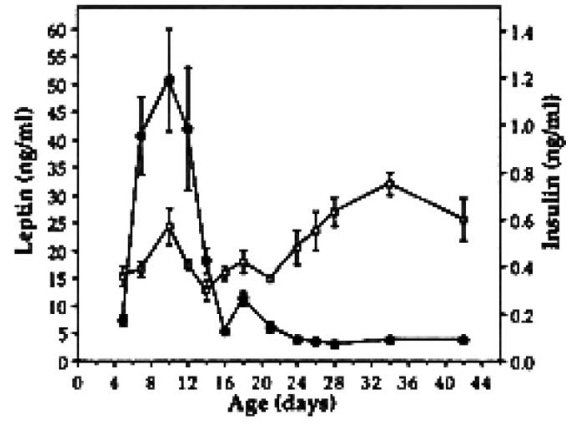

FIG. 4. Circulatory levels of leptin, estradiol, and insulin in neonatal female mice. (A) The leptin spike at 10 days of age preceding that of estradiol is consistent with a stimulatory role of leptin on the reproductive axis around the time of puberty. (B) The coincident rise in leptin and insulin at 10 days of age suggests that leptin and insulin may act together to stimulate the reproductive system. [Reprinted with permission from Ahima RS, Prakabakaran D, Flier JS 1998 Postnatal leptin surge and regulation of circadian rhythm of leptin by feeding. J Clin Invest 101:1020-1027.]

redundancy of supportive mechanisms ensuring the survival of the reproductive system - and therefore of the species - suggest that leptin might recruit other factors (e.g., insulin, IGF-1) to stimulate the release of gonadotropin-releasing hormone $(\mathrm{GnRH})$ and open the gate of the reproductive system. Variations in the expression of leptin's cofactors at critical times during the progression to puberty may be detrimental to the reproductive system. For example, disruption of insulin signaling in the brain has revealed disturbances of the reproductive system (Burks et al., 2000). ICV injections of IGF-1 have been known for some time to induce early puberty (Hiney et al., 1991,1996). Thus, the actions of leptin, insulin, and IGF-1 in the brain could constitute a driving force aimed at the stimulation and firing of the reproductive system.

A mechanism of action of leptin on the reproductive system remains elusive. However, two critical components of the leptin energy homeostasis pathway have been ruled out as playing a role in reproduction and, in fact, have dissociated the obesity from the sterility phenotypes. As previously stated, MC4R KO mice are obese but fertile, ruling out that the MC4R and its downstream targets are critical for reproduction. Thus, bifurcation from the leptin-energy homeostasis pathway could occur at the MC4-R or upstream from it. Furthermore, the role of orexigenic NPY appears to be central for the leptin-reproductive pathway. NPY inhibits reproductive function in male and female rats (Clark et al., 1985). Its overexpression in obese-sterile, leptindeficient $o b / o b$ mice is reduced by leptin treatment (Stephens et al., 1995), which is accompanied by a rescuing of the sterility phenotype (Chehab et al., 1996). 
NPY's inhibitory effect on reproductive function appears to be mediated by the $\mathrm{Y} 4$ receptor, since $o b / o b$ mice homozygous for an Y4 receptor deletion remain obese but are fertile (Sainsbury et al., 2002). The exclusion of a major leptin signaling event in the hypothalamus stemmed from the finding that mutation of the critical tyrosine 1138 phosphorylation site in the long form of the leptin receptor, largely responsible for signal transducer and activator of transcription (STAT)-3 activation, resulted in an obese but fertile mouse (Bates et al., 2003). Thus, the pathway elicited by tyrosine 1138 phosphorylation is not critical for reproduction. These observations suggest that the leptin-reproductive pathway bifurcates from the leptin-energy homeostasis pathway prior to the MC4-R and may involve a separate signaling pathway at other leptin receptor sites. The complexity of this pathway is demonstrated by the fact that modifier genes rescued the sterility phenotype of leptin-deficient mice, demonstrating the multifactorial nature of the leptin-reproductive pathway (Ewart-Toland et al., 1999; Qiu et al., 2001a).

\section{Leptin and the Melanocortin System}

It has been demonstrated that a major downstream target of leptin-binding neurons is a downregulation of NPY neurons and a stimulation of MC4R neurons, which act to stimulate and inhibit food intake, respectively (Cowley et al., 2001). While this topic has been extensively reviewed, the issue of adultonset obesity, as in agouti yellow obese mice $\left({ }^{\mathrm{y}} \mathrm{A}\right)$, has received little attention. The molecular defect in ${ }^{\mathrm{y}} \mathrm{A}$ mice has been elucidated and consists of a blockade at the MC4R by the agouti protein, which normally is expressed only in melanocytes, but becomes ubiquitously expressed in the agouti mouse. As a result, it competes with $\alpha$-MSH binding at the MC4R (Bultman et al., 1992; Miller et al., 1993; Lu et al., 1994). These studies led to the discovery of agouti-related protein (AgRP) (Ollmann et al., 1997), which is the endogenous competitor of $\alpha-\mathrm{MSH}$. AgRP and $\alpha-\mathrm{MSH}$ act together to regulate energy homeostasis (Ebihara et al., 1999). Interestingly, AgRP overexpression in transgenic mice leads to obesity (Ollman et al., 1997), whereas its deletion by gene targeting did not result in any obvious phenotype, even in the absence of NPY (Qian et al., 2002). This suggests that other factors may regulate energy homeostasis via the MC4R, either in the presence or absence of AgRP and NPY.

The issue of adult-onset obesity is central and has been neglected. For example, in the ${ }^{\mathrm{y}} \mathrm{A}$ mouse, despite the ubiquitous expression of agouti protein and its antagonism of melanocyte signaling and pigmentation from an early age, it is not clear why antagonism at the MC4R is delayed and not evident from a young age. To address whether leptin sensitivity is reduced from a young age in agouti mice, we crossed LepTg mice with ${ }^{\mathrm{y}} \mathrm{A}$ mice and generated double heterozygotes for ${ }^{\mathrm{y}} \mathrm{A}$ and the leptin transgene. The resulting mice were largely devoid of 
adipose mass, similar to the transgenic mice, but showed the characteristic agouti color of ${ }^{\mathrm{y}} \mathrm{A}$ mice (Figure 5). The statistical differences in body weight, reflecting the lean phenotype of the double heterozygotes, did not last beyond 6 weeks in females and 8 weeks in males (Figure 5), when obesity started to become evident and the lean phenotype caused by transgenic hyperleptinemia started to wane. The color coat of the mutant mice demonstrated expression of the agouti protein from a young age; studies have shown that the MC4R also is expressed from a young age (Mountjoy and Wild, 1998). Then why is the obesity associated with the lack of neuronal MC4R signaling not manifested from a young age, as in $o b / o b$ and $d b / d b$ mice, but manifested at a later age, as in ${ }^{\mathrm{y}} \mathrm{A}$ and MC4R KO mice? One would have to speculate that neuronal projections downstream of the MC4R conceivably either do not develop or fail to be activated until a later age. Thus, these animal models will be valuable in elucidating pathways downstream of MC4R neurons that may develop to counteract leptin sensitivity.

\section{Leptin and the Sympathetic Nervous System}

The binding of leptin to its receptor in the arcuate nucleus eventually is reflected by the adrenergic stimulation of lipolysis (Collins et al., 1996) on adipocytes via beta3 adrenergic receptors ( $\beta 3 \mathrm{AR}$ ). Deletion of the $\beta 3 \mathrm{AR}$ by gene targeting did not yield to overt obesity, due to an upregulation and activation of $\beta 1 \mathrm{AR}$ and $\beta 2 \mathrm{ARs}$ (Susulic et al., 1995). In addition, deletion of $\beta 1,-2$, and -3
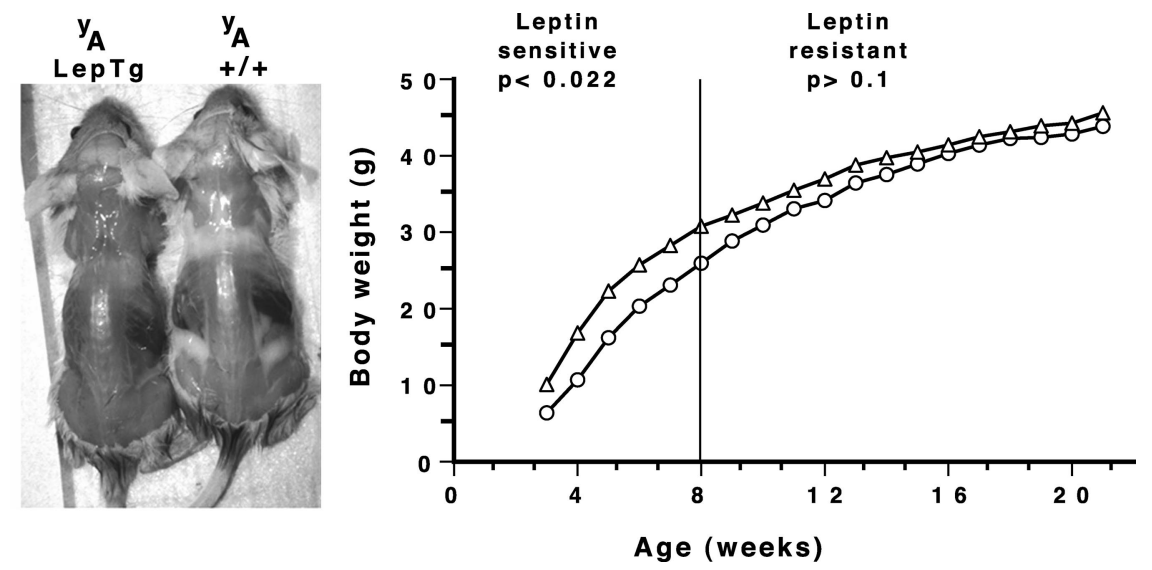

FIG. 5. Sensitivity and resistance of agouti yellow $\left({ }^{y} \mathrm{~A}\right)$ mice to transgenic leptin. The photograph shows the lack of subcutaneous adipose mass in 6-week-old agouti LepTg males ( ${ }^{\mathrm{y}} \mathrm{A}$ LepTg), compared to yellow agouti $\left({ }^{\mathrm{y}} \mathrm{A}+/+\right)$ controls without transgenic hyperleptinemia. The growth curve shows the biphasic states of the ${ }^{\mathrm{y}} \mathrm{A} / \mathrm{LepTg}$ mice $(\mathrm{O})$ between 3-8 weeks of age, when their body weights are significantly less than those of ${ }^{\mathrm{y}} \mathrm{A}+/+$ mice $(\triangle)$. 
ARs yielded mice that were slightly obese on a chow diet but grossly obese on a high-fat diet (Bachman et al., 2002). This suggested that $\beta$ ARs are necessary to counteract diet-induced obesity (DIO). We asked whether the leptin-mediated stimulation of the SNS acting on adipocytes would be attenuated by the absence of $\beta 3 \mathrm{AR}$ on adipocytes. This effect would be most noticeable in animals with no or little fat (e.g., LepTg mice). Thus, generation of LepTg mice with no $\beta 3 \mathrm{AR}$ resulted in a lean phenotype similar to that of LepTg mice with $\beta 3 \mathrm{AR}$, as judged by their growth curves (Ke et al., 2003) (Figure 6). This infers a normal response of adipocytes to leptin-mediated SNS activation of lipolysis. Therefore, leptinmediated activation of the SNS is indifferent to the absence of $\beta 3 \mathrm{AR}$, which are chiefly found on adipocytes.

Another axis that has been investigated is the renal axis, with possible connections to hypertension. Leptin treatment caused a dose-dependent increase in sympathetic nerve activity to the kidney (Haynes et al., 1997). This increase could be blocked by the MC4-R antagonist SHU9119, thereby involving the melanocortin system in the sympathoexcitatory effects of leptin on the kidney (Haynes et al., 1999). LepTg mice consistently had elevated blood pressure, whereas the low blood pressure characteristic of $o b / o b$ mice was reversed with leptin treatment (Aizawa-Abe et al., 2000). However, ICV administrations of SHU9119 increased food intake in the LepTg mice but did not affect their blood pressure, suggesting that the leptin-mediated effect on blood pressure involves a
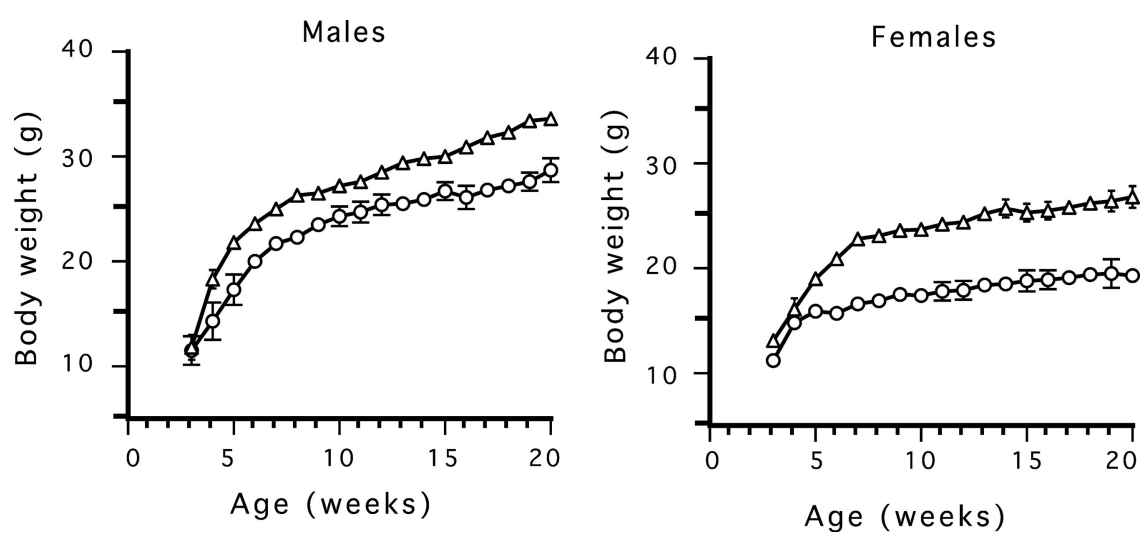

FIG. 6. Transgenic hyperleptinemia exerts its effects independently of beta3-adrenergic receptors $(\beta 3 \mathrm{ARs})$. Growth curves of $\beta 3 \mathrm{AR} \mathrm{KO}$ mice $(\beta \mathrm{ARKO})$ with $(\bigcirc)$ and without $(\triangle)$ transgenic hyperleptinemia. The body weights of the LepTg mice on a null $\beta 3 \mathrm{AR}$ background remain smaller than those of $\beta$ ARKO mice without hyperleptinemia, demonstrating the lack of specificity of the leptin-mediated response to $\beta 3$ ARs. [Reprinted from Ke Y, Qiu J, Ogus S, Shen WJ, Kraemer PB, Chehab FF 2003 Overexpression of leptin in transgenic mice leads to decreased basal lipolysis, PKA activity and perilipin levels. BBRC 312:1165-1170.] 
different pathway than the melanocortin system. Thus, to reconcile the differences between the SHU9119 blockade of the leptin-mediated sympathetic activation of the kidney and its lack of effect on the blood pressure of the LepTg mice, one would have to assume that the two pathways are centrally divergent at the MC4-R.

\section{Leptin and the Bone Axis}

Increased weight bearing caused by obesity results in increased bone remodeling and decreased bone removal. This observation is significant in obese, postmenopausal women, who show diminished rates of hip fractures caused by osteoporosis. Thus, a mechanism linking obesity and osteoporosis would be of great interest in the treatment of osteoporosis in nonobese women. The observation that ICV leptin treatment of normal and leptin-deficient $o b / o b$ mice resulted in bone loss led to the hypothesis that leptin participates in the modulation of bone formation via its action on the hypothalamus, acting as an inhibitor of this process (Ducy et al., 2000) independently of its anorexigenic function (Takeda et al., 2002). Based on an increased bone mass in leptindeficient mice, we asked whether an excess of leptin, as found in the LepTg mice, would result in decreased bone mass. Histomorphometric studies showed that bone formation was not affected by transgenic hyperleptinemia (F.F. Chehab and M. Horowitz, unpublished observations), despite a modest and significant decrease in bone weight, which could be attributed to the smaller weight and lean phenotype of the LepTg mice. Thus, leptin deficiency strengthens bone formation, while its abundance in organisms that respond to hyperleptinemia does not appear to cause a detrimental effect on bone remodeling.

\section{Resistance to Transgenic Hyperleptinemia}

It is clear from the phenotype of LepTg mice that they chronically respond to transgenic hyperleptinemia, as evidenced by reductions in food intake and fat mass, two parameters that are characteristic of a leptin response. We found that even though the LepTg mice continue to secrete transgenic leptin throughout their life, there are at least three situations that make them resistant to transgenic hyperleptinemia: aging, a high-fat diet, and genetics (Figure 7).

When maintained on a C57BL/6J/DBA heterogeneous genetic background, the LepTg mice exhibit a lean phenotype characterized by very little fat mass, which gradually builds up to approximate that of normal mice around 33-36 weeks of age (Qiu et al., 2001b). On a pure C57BL/6J genetic background, the LepTg mice remain lean for a longer period of time than on a mixed genetic background but eventually also gain large amounts of fat that remain, however, significantly less than those of nontransgenic littermates. Our observation that the LepTg mice fail to remain lean over time, an effect more pronounced in males than females, is puzzling and interesting. It has been reported that aging results 

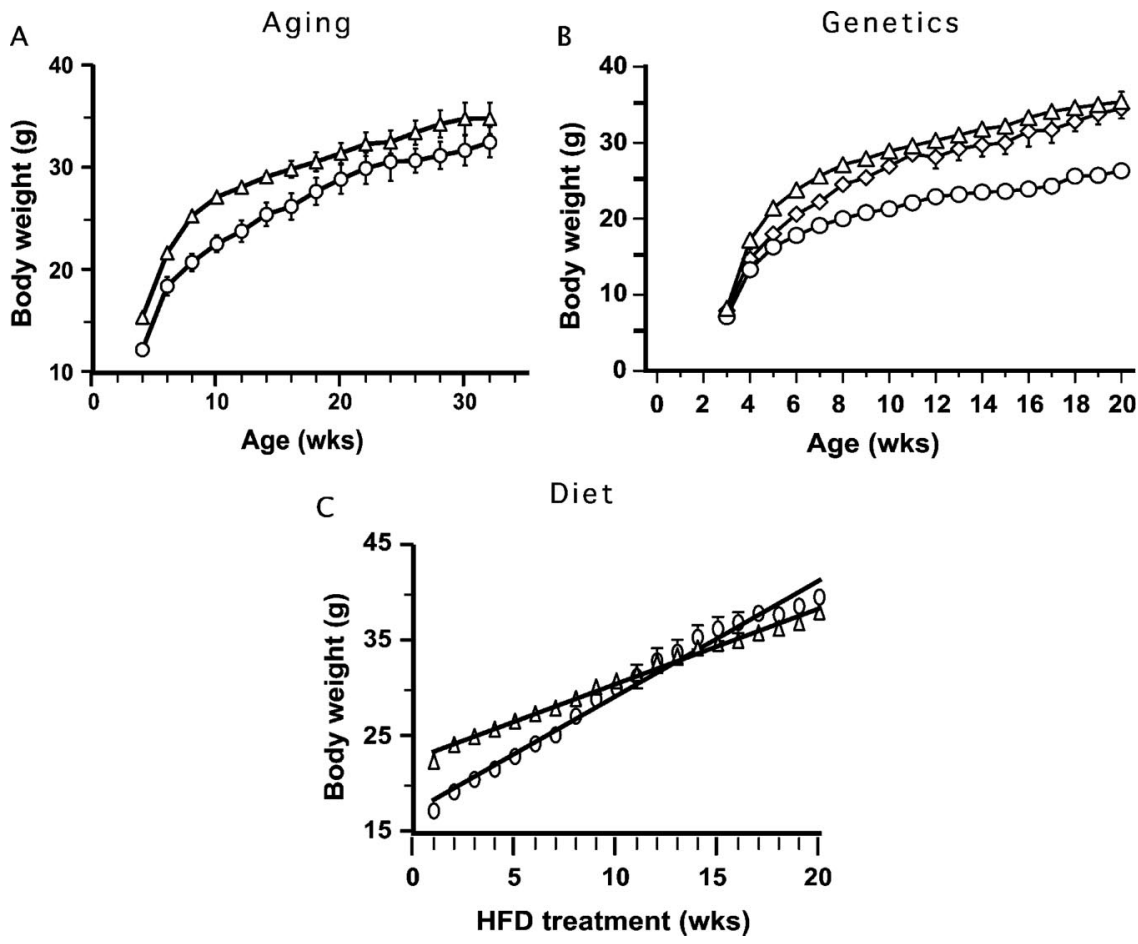

FIG. 7. Resistance to transgenic hyperleptinemia as a result of aging, genetic background, and diet-induced obesity (DIO). (A) At a young age, the body weights of LepTg mice on a mixed genetic background $(\bigcirc)$ are lower than those of normal mice $(\triangle)$, reflecting lower adiposity, but then start to approach the body weights of normal mice at a later age. (B) Genetic resistance to transgenic hyperleptinemia in LepTg males bred on a mixed genetic background $(\diamond)$ is demonstrated by their normal body weight, compared to WT $(\triangle)$ and LepTg $(\bigcirc)$ mice on the same genetic background. (C) Body weights of high-fat diet-fed C57BL/6J normal $(\triangle)$ and LepTg $(\bigcirc)$ mice show the precipitous DIO of LepTg mice. [(A) Reprinted with permission from Qiu J, Ogus S, Lu R, Chehab FF 2001 Transgenic mice overexpressing leptin accumulate adipose mass at an older, but not younger, age. Endocrinology 142:348-358. Copyright The Endocrine Society; (C) Modified with permission from Ogus S, Ke Y, Qiu J, Wang B, Chehab FF 2003 Hyperleptinemia precipitates diet-induced obesity in transgenic mice overexpressing leptin. Endocrinology 144:2865-2869. Copyright The Endocrine Society.]

in a leptin resistance state (Scarpace et al., 2000a,b). Thus, it would make sense to assume the same for the LepTg mice. Whether the effects of functional transgenic hyperleptinemia become blunted with aging or whether a mechanism that supercedes the transgenic leptin effect becomes established with age remains to be determined. However, our studies tend to favor the latter hypothesis because transgenic mice that have accumulated adipose mass with age remain sensitive to peripheral administrations of large doses of leptin (Qiu et al., 2001b). 
An unexpected finding underlying the loss of effect associated with functional transgenic hyperleptinemia was a high-fat diet. Since the young LepTg mice are sensitive to transgenic hyperleptinemia — as indicated by a reduction in food intake and adipose tissue mass - we reasoned that they actually would be resistant or show at least an attenuated obesity on a high-fat diet treatment. This was clearly not the case when they were fed a diet consisting of $42 \%$ milk fat, as they manifested a more-precipitous obesity than that of normal mice fed the same diet (Ogus et al., 2003). This interesting finding raises a number of issues as to the cause of their resistance to transgenic hyperleptinemia. In the absence of significant differences in high-fat food intake, one should look for differences in energy expenditure, metabolism, or diet composition. It is possible that the levels of hyperleptinemia were not sufficient to counteract the rapid buildup of adipose mass, indicating that the ratio of leptin to fat accumulation would be the culprit of the resulting phenotype. Moreover, the composition of the high-fat diet, which consisted of $61 \%$ saturated and 39\% unsaturated fats, may be critical. Thus, feeding the LepTg mice different amounts and types of fat might provide clues about the interactions between their hyperleptinemia and their diet, possibly extending the resulting observations to the broader problem of hyperleptinemia in DIO in animals and humans.

Another interesting finding in our LepTg mice is the fact that some on the mixed genetic background exhibit a transgenic hyperleptinemia that is not associated with a lean phenotype, even from a young age (Figure 7). When backcrossed to the $\mathrm{C} 57 \mathrm{BL} / 6 \mathrm{~J}$ genetic background for $6-10$ generations, this effect is lost, pointing to a powerful effect of modifier genes from the C57BL/6J and DBA/2J genetic backgrounds. Backcrossing the LepTg mice to the DBA/2J background revealed that, at the N5 generation, the LepTg mice remain lean, similar to C57BL/6J LepTg mice. Thus, genetic leptin resistance must have arisen from a polygenic interaction of the two genomes. Furthermore, crosses of genetically resistant LepTg mice did not result in recapitulation of the phenotype according to Mendel's laws for single-gene disorders. Thus, it is unlikely that dominant or recessive genes accounted for this early leptin resistance phenotype. Instead, it suggests that modifier genes had accumulated in these mice but that genetic crosses allowed their segregation. Although these findings reinforce the effect of genetics on the phenotype of leptin resistance, along with the data mentioned earlier, they pinpoint what has commonly been suspected: that complex genetics account for the common DIO phenotype.

\section{Perspectives on Mechanisms of Leptin Resistance}

Leptin resistance refers to a state of elevated leptin levels without a lean phenotype but, paradoxically, with an obese state. It has been suggested that the hypothalamus may be insensitive to elevated leptin levels but would, on the 
contrary, sense low leptin levels, such as in fasting states. This would activate a survival response that would conserve energy resources by shutting down, for example, the reproductive system. Remarkably, the response to fasting can be rescued by leptin injections, demonstrating that leptin mediates the starvationinduced response (Ahima et al., 1996).

What distinguishes LepTg mice with elevated leptin levels and a clear response to hyperleptinemia from hyperleptinemia in common obesity remains for the most part unknown. It is unlikely, but still not completely ruled out, that the primary defect could lie in the saturation transport of leptin to the hypothalamus. There appears to be enough leeway to allow large quantities of leptin (such as in LepTg mice) to elicit a physiological response (Ogawa et al., 1999; Qiu et al., 2001b). The culprit may, however, be in the diet, which could block leptin's access to the hypothalamus or its central action. It has been shown that prolonged, high-fat diet feeding of normal mice fails and reduces STAT-3 activation in the hypothalamus following peripheral and central administrations of leptin, respectively (El-Haschimi et al., 2000). The contribution of the diet and its mechanisms of action to the establishment of a leptin-resistant state in LepTg mice will be invaluable in deciphering pathways that result in dysfunctional hyperleptinemia. One possibility is that components of a high-fat diet might alter the permeability of leptin to the brain and reduce leptin signaling in the hypothalamus.

\section{Evolutionary Significance of Hyperleptinemia}

The possibility that resistance to hyperleptinemia might have evolved as a protective mechanism to ensure the survival of an organism is a worthwhile hypothesis. As previously noted, LepTg mice are cold sensitive and succumb rapidly to a low temperature. Should a similar situation arise in wild habitats, such mice would be quickly eliminated by natural selection, unless they are capable of developing leptin resistance. This is particularly significant for hibernating animals, which stock up on energy stores prior to hibernation, increasing their adiposity and leptin levels. Should they fail to develop leptin resistance, the process of adipose mass deposition would fail. Another example is pregnancy. We have shown that leptin resistance is established in midpregnancy in normal mice (Mounzih et al., 1998) as a mechanism to increase energy intake to build up enough adipose tissue in anticipation of the large energy requirements of lactation. If the mother fails to build up adipose tissue, lactation and survival of the pups would be seriously jeopardized. Therefore, the need to develop a resistance to hyperleptinemia is teologically warranted and would protect the organism against the detrimental effects of functional hyperleptinemia to ensure its survival. Thus, although leptin resistance in pregnancy makes sense and is essential, it occasionally extends beyond gestation, resulting in postpartum 
weight retention. This again demonstrates a close interaction between the reproductive system, leptin signaling, and obesity.

\section{Concluding Remarks}

Much remains to be learned about the biology of leptin and its direct and indirect effects on various systems. The use of leptin-deficient, leptin-resistant, and leptin-overexpressing mice has demonstrated the detrimental consequences of leptin resistance and sensitivity, albeit in different ways. Animal models will continue to unravel the biology of leptin and are destined to unlock leptin resistance and provide a treatment for obesity. However, timed leptin resistance, as in pregnancy, is essential and would need to be maintained to ensure the survival of the next generation.

\section{REFERENCES}

Ahima RS, Prakabakaran D, Mantzoros C, Qu D, Lowell B, Maratos-Flier E, Flier JS 1996 Role of leptin in the neuroendocrine response to fasting. Nature 382:250-252

Ahima RS, Dushay J, Flier SN, Prakabakaran D, Flier JS 1997 Leptin accelerates the onset of puberty in normal female mice. J Clin Invest 99:391-395

Ahima RS, Prakabakaran D, Flier JS 1998 Postnatal leptin surge and regulation of circadian rhythm of leptin by feeding. J Clin Invest 101:1020-1027

Aizawa-Abe M, Ogawa Y, Masuzaki H, Ebihara K, Satoh N, Iwai H, Matsuoka N, Hayashi T, Hosoda K, Inoue G, Yoshimasa Y, Nakao K 2000 Pathophysiological role of leptin in obesity-related hypertension. J Clin Invest 105:1243-1252

Bachman ES, Dhillon H, Zhang CY, Cinti S, Bianco AC, Kobilka BK, Lowell BB 2002 betaAR signaling required for diet-induced thermogenesis and obesity resistance. Science 297:843845

Banks WA, Kastin AJ, Huang W, Jaspan JB, Maness LM 1996 Leptin enters the brain by a saturable system independent of insulin. Peptides 17:305-311

Barker-Gibb ML, Sahu A, Pohl CR, Plant TM 2002 Elevating circulating leptin in prepubertal male rhesus monkeys (Macaca mulatta) does not elicit precocious gonadotropin-releasing hormone release, assessed indirectly. J Clin Endocrinol Metab 87:4976-4983

Bates SH, Stearns WH, Dundon TA, Schubert M, Tso AW, Wang Y, Banks AS, Lavery HJ, Haq AK, Maratos-Flier E, Neel BG, Schwartz MW, Myers MG Jr 2003 STAT3 signaling is required for leptin regulation of energy balance but not reproduction. Nature 421:856-859

Berardinelli, W 1954 An undiagnosed endocrinometabolic syndrome: report of two cases. J Clin Endocrinol Metab 14:193

Bultman SJ, Michaud EJ, Woychik RP 1992 Molecular characterization of the mouse agouti locus. Cell 71:1195-11204

Burks DJ, de Mora JF, Schubert M, Withers DJ, Myers MG, Towery HH, Altamuro SL, Flint CL, White MF 2000 IRS-2 pathways integrate female reproduction and energy homeostasis. Nature 407:377-382

Campfield LA, Smith,FJ, Guisez Y, Devos R, Burn P 1995 Recombinant mouse OB protein: evidence for a peripheral signal linking adiposity and central neural networks. Science 269:546-549

Carro E, Pinilla L, Seoane LM, Considine RV, Aguilar E, Casanueva FF, Dieguez C 1997 Influence of endogenous leptin tone on the estrous cycle and luteinizing hormone pulsatility in female rats. Neuroendocrinology 66:375-377 
Cederberg AL, Gronning M, Ahren B, Tasken K, Carlsson P, Enerbäck S 2001 FOXC2 is a winged helix gene that counteracts obesity, hypertriglyceridemia, and diet-induced insulin resistance. Cell 106:563-573

Chehab FF, Lim ME, Lu, R 1996 Correction of the sterility defect in homozygous obese female mice by treatment with the recombinant human leptin. Nature Genet 12:318-320

Chehab FF, Mounzih K, Lu R, Lim ME 1997 Early onset of reproductive function in normal female mice treated with leptin. Science 275:88-90

Chen G, Koyama K, Yuan X, Lee Y, Zhou YT, O’Doherty R, Newgard CB, Unger RH 1996 Disappearance of body fat in normal rats induced by adenovirus-mediated leptin gene therapy. Proc Natl Acad Sci USA 93:14795-14799

Cheung CC, Thornton JE, Kuijper JL, Weigle DS, Clifton DK, Steiner RA 1997 Leptin is a metabolic gate for the onset of puberty in the female rat. Endocrinology 138:855-858

Clark JT, Kalra PS, Kalra SP 1985 Neuropeptide Y stimulates feeding but inhibits sexual behavior in rats. Endocrinology 117:2435-2442

Clement K, Vaisse C, Lahlou N, Cabrol S, Pelloux V, Cassuto D, Gourmelen M, Dina C, Chambaz J, Lacorte JM, Basdevant A, Bougneres P, Lebouc Y, Froguel P, Guy-Grand B 1998 A mutation in the human leptin receptor gene causes obesity and pituitary dysfunction. Nature 392:398-401

Coleman DJ, Hummel KH 1969 Effect of parabiosis of normal with genetically diabetic mice. Am J Physiol 217:1298-1304

Collins S, Kuhn CM, Petro AE, Swick AG, Chrunyk BA, Surwit RS 1996 Role of leptin in fat regulation. Nature 380:677

Considine RV, Sinha MK, Heiman ML, Kriauciunas A, Stephens TW, Nyce MR, Ohannesian JP, Marco CC, McKee LJ, Bauer TL, et al. 1996 Serum immunoreactive-leptin concentrations in normal-weight and obese humans. N Engl J Med 334:292-295

Cowley MA, Smart JL, Rubinstein M, Cerdan MG, Diano S, Horvath TL, Cone RD, Low MJ 2001 Leptin activates anorexigenic POMC neurons through a neural network in the arcuate nucleus. Nature 41:480-484

Cummings DE, Brandon EP, Planas JV, Motamed K, Idzerda RL, McKnight GS 1996 Genetically lean mice result from targeted disruption of the RII beta subunit of protein kinase A. Nature 382:622-626

Dearth RK, Hiney JK, Dees WL 2000 Leptin acts centrally to induce the prepubertal secretion of luteinizing hormone in the female rat. Peptides 21:387-392

Ducy P, Amling M, Takeda S, Priemel M, Schilling AF, Beil FT, Shen J, Vinson C, Rueger JM, Karsenty G 2000 Leptin inhibits bone formation through a hypothalamic relay: a central control of bone mass. Cell 100:197-207

Ebihara K, Ogawa Y, Katsuura G, Numata Y, Masuzaki H, Satoh N, Tamaki M, Yoshioka T, Hayase M, Matsuoka N, Aizawa-Abe M, Yoshimasa Y, Nakao K 1999 Involvement of agouti-related protein, an endogenous antagonist of hypothalamic melanocortin receptor, in leptin action. Diabetes 48:2028-2033

Ebihara K, Ogawa Y, Masuzaki H, Shintani M, Miyanaga F, Aizawa-Abe M, Hayashi T, Hosoda K, Inoue G, Yoshimasa Y, Gavrilova O, Reitman ML, Nakao K 2001 Transgenic overexpression of leptin rescues insulin resistance and diabetes in a mouse model of lipoatrophic diabetes. Diabetes 50:1440-1448

Elchebly M, Payette P, Michaliszyn E, Cromlish W, Collins S, Loy AL, Normandin D, Cheng A, Himms-Hagen J, Chan CC, Ramachandran C, Gresser MJ, Tremblay ML, Kennedy BP 1999 Increased insulin sensitivity and obesity resistance in mice lacking the protein tyrosine phosphatase-1B gene. Science 283:1544-1548 
El-Haschimi K, Pierroz DD, Hileman SM, Bjorbaek C, Flier JS 2000 Two defects contribute to hypothalamic leptin resistance in mice with diet-induced obesity. J Clin Invest 105:18271832

Ewart-Toland A, Mounzih K, Qiu J, Chehab FF 1999 Effect of the genetic background on the reproduction of leptin-deficient obese mice. Endocrinology 140:732-738

Farooqi IS, Jebb SA, Langmack G, Lawrence E, Cheetham CH, Prentice AM, Hughes IA, McCamish MA, O'Rahilly S 1999 Effects of recombinant leptin therapy in a child with congenital leptin deficiency. N Engl J Med 341:879-884

Flier JS 1998 Clinical review 94: What's in a name? In search of leptin's physiologic role. J Clin Endocrinol Metab 83:1407-1413

Flier JS, Cook KS, Usher P, Spiegelman BM 1987 Severely impaired adipsin expression in genetic and acquired obesity. Science 237:405-408

Halaas JL, Gajiwala KS, Maffei M, Cohen SL, Chait BT, Rabinowitz D, Lallone RL, Burley SK, Friedman JM 1995 Weight-reducing effects of the plasma protein encoded by the obese gene. Science 269:543-546

Hamilton CR, Scully RE, Kliman B 1972 Hypogonadotrophism in Prader-Willi syndrome. Am J Med 52:322

Himms-Hagen J 1984 Brown adipose tissue thermogenesis, energy balance, and obesity. Can J Biochem Cell Biol 62:610-617

Haynes WG, Morgan DA, Walsh SA, Mark AL, Sivitz WI 1997 Receptor-mediated regional sympathetic nerve activation by leptin. J Clin Invest 100:270-278

Haynes WG, Morgan DA, Djalali A, Sivitz WI, Mark AL 1999 Interactions between the melanocortin system and leptin in control of sympathetic nerve traffic. Hypertension 33:542547

Hiney JK, Ojeda SR, Dees WL 1991 Insulin-like growth factor I: a possible metabolic signal involved in the regulation of female puberty. Neuroendocrinology 54:420-423

Hiney JK, Srivastava V, Nyberg CL, Ojeda SR, Dees WL 1996 Insulin-like growth factor I of peripheral origin acts centrally to accelerate the initiation of female puberty. Endocrinology 137:3717-3728

Hotamisligil GS, Shargill NS, Spiegelman BM 1993 Adipose expression of tumor necrosis factor-alpha: direct role in obesity-linked insulin resistance. Science 259:87-91

Huszar D, Lynch CA, Fairchild-Huntress V, Dunmore JH, Fang Q, Berkemeier LR, Gu W, Kesterson RA, Boston BA, Cone RD, Smith FJ, Campfield LA, Burn P, Lee F 1997 Targeted disruption of the melanocortin-4 receptor results in obesity in mice. Cell 88:131-141

Ioffe E, Moon B, Connolly E, Friedman JM 1998 Abnormal regulation of the leptin gene in the pathogenesis of obesity. Proc Natl Acad Sci USA 195:11852-11857

Jones KL 1988 Smith's Recognizable Patterns of Human Malformation, edit 4. Philadelphia: Saunders; 530

Ke Y, Qiu J, Ogus S, Shen WJ, Kraemer PB, Chehab FF 2003 Overexpression of leptin in transgenic mice leads to decreased basal lipolysis, PKA activity and perilipin levels. BBRC 312:1165-1170

Klaman LD, Boss O, Peroni OD, Kim JK, Martino JL, Zabolotny JM, Moghal N, Lubkin M, Kim YB, Sharpe AH, Stricker-Krongrad A, Shulman GI, Neel BG, Kahn BB 2000 Increased energy expenditure, decreased adiposity, and tissue-specific insulin sensitivity in protein-tyrosine phosphatase 1B-deficient mice. Mol Cell Biol 20:5479-5489

Lane PW 1959 The pituitary-gonad response of genetically obese mice in parabiosis with thin and obese siblings. Endocrinology 65:863-868

Lee Y, Wang MY, Kakuma T, Wang ZW, Babcock E, McCorkle K, Higa M, Zhou YT, Unger RH 2001 Liporegulation in diet-induced obesity. The antisteatotic role of hyperleptinemia. J Biol Chem 276:5629-5635 
Lord GM, Matarese G, Howard JK, Baker RJ, Bloom SR, Lechler RI 1998 Leptin modulates the T-cell immune response and reverses starvation-induced immunosuppression. Nature 394: 897-901

Lu D, Willard D, Patel IR, Kadwell S, Overton L, Kost T, Luther M, Chen W, Woychik RP, Wilkison WO, et al. 1994 Agouti protein is an antagonist of the melanocyte-stimulatinghormone receptor. Nature 371:799-802

Martinez-Botas J, Anderson JB, Tessier D, Lapillonne A, Chang BH, Quast MJ, Gorenstein D, Chen KH, Chan L 2000 Absence of perilipin results in leanness and reverses obesity in Lepr $(d b / d b)$ mice. Nature Genet 26:474-479

Miller MW, Duhl DM, Vrieling H, Cordes SP, Ollmann MM, Winkes BM, Barsh GS 1993 Cloning of the mouse agouti gene predicts a secreted protein ubiquitously expressed in mice carrying the lethal yellow mutation. Genes Dev 7:454-467

Minokoshi Y, Kim YB, Peroni OD, Fryer LG, Muller C, Carling D, Kahn BB 2002 Leptin stimulates fatty-acid oxidation by activating AMP-activated protein kinase. Nature 415:339-343

Moitra J, Mason MM, Olive M, Krylov D, Gavrilova O, Marcus-Samuels B, Feigenbaum L, Lee E, Aoyama T, Eckhaus M, Reitman ML, Vinson C 1998 Life without white fat: a transgenic mouse. Genes Dev 12:3168-3181

Montague CT, Farooqi IS, Whitehead JP, Soos MA, Rau H, Wareham NJ, Sewter CP, Digby JE, Mohammed SN, Hurst JA, Cheetham CH, Earley AR, Barnett AH, Prins JB, O'Rahilly S 1997 Congenital leptin deficiency is associated with severe early-onset obesity in humans. Nature 387:903-908

Mountjoy KG, Wild JM 1998 Melanocortin-4 receptor mRNA expression in the developing autonomic and central nervous systems. Brain Res Dev 107:309-314

Mounzih K, Qiu J, Ewart-Toland A, Chehab FF 1998 Leptin is not necessary for gestation and parturition but regulates maternal nutrition via a leptin resistance state. Endocrinology 139:5259-5262

Nagatani S, Guthikonda P, Foster DL 2000 Appearance of a nocturnal peak of leptin secretion in the pubertal rat. Horm Behav 37:345-352

Ogawa Y, Masuzaki H, Hosoda K, Aizawa-Abe M, Suga J, Suda M, Ebihara K, Iwai H, Matsuoka N, Satoh N, Odaka H, Kasuga H, Fujisawa Y, Inoue G, Nishimura H, Yoshimasa Y, Nakao K 1999 Increased glucose metabolism and insulin sensitivity in transgenic skinny mice overexpressing leptin. Diabetes 48:1822-1829

Ogus S, Ke Y, Qiu J, Wang B, Chehab FF 2003 Hyperleptinemia precipitates diet-induced obesity in transgenic mice overexpressing leptin. Endocrinology 144:2865-2869

Ollmann MM, Wilson BD, Yang YK, Kerns JA, Chen Y, Gantz I, Barsh GS 1997 Antagonism of central melanocortin receptors in vitro and in vivo by agouti-related protein. Science 278:135-138

Pelleymounter MA, Cullen MJ, Baker MB, Hecht R, Winters D, Boone T, Collins F 1995 Effects of the obese gene product on body weight regulation in $o b / o b$ mice. Science 269:540-543

Plant TM, Durrant AR 1997 Circulating leptin does not appear to provide a signal for triggering the initiation of puberty in the male rhesus monkey (Macaca mulatta). Endocrinology 138:4505-4508

Qian S, Chen H, Weingarth D, Trumbauer ME, Novi DE, Guan X, Yu H, Shen Z, Feng Y, Frazier E, Chen A, Camacho RE, Shearman LP, Gopal-Truter S, MacNeil DJ, Van der Ploeg LH, Marsh DJ 2002 Neither agouti-related protein nor neuropeptide Y is critically required for the regulation of energy homeostasis in mice. Mol Cell Biol 22:5027-5035

Qiu J, Ogus S, Mounzih K, Ewart-Toland A, Chehab FF 2001a Leptin-deficient mice backcrossed to the BALB/cJ genetic background have reduced adiposity, enhanced fertility, normal body temperature, and severe diabetes. Endocrinology 142:3421-3425

Qiu J, Ogus S, Lu R, Chehab FF 2001b Transgenic mice overexpressing leptin accumulate adipose mass at an older, but not younger, age. Endocrinology 142:348-358 
Sainsbury A, Schwarzer C, Couzens M, Jenkins A, Oakes SR, Ormandy CJ, Herzog H 2002 Y4 receptor knockout rescues fertility in $o b / o b$ mice. Genes Dev 16:1077-1088

Satoh N, Ogawa Y, Katsuura G, Numata Y, Masuzaki H, Yoshimasa Y, Nakao K 1998 Satiety effect and sympathetic activation of leptin are mediated by hypothalamic melanocortin system. Neurosci Lett 249:107-110

Savage DB, O'Rahilly S 2002 Leptin: a novel therapeutic role in lipodystrophy. J Clin Invest 109:1285-1286

Scarpace PJ, Matheny M, Moore RL, Tumer N 2000a Impaired leptin responsiveness in aged rats. Diabetes 49:431-435

Scarpace PJ, Matheny M, Shek EW 2000b Impaired leptin signal transduction with age-related obesity. Neuropharmacology 39:1872-1879

Seip M, Trygstad O 1963 Generalized lipodystrophy. Arch Dis Child 38:447

Shimomura S, Hammer RE, Richardson JA, Ikemoto S, Bashmakov Y, Goldstein JL, Brown MS 1998 Insulin resistance and diabetes mellitus in transgenic mice expressing nuclear SREBP-1c in adipose tissue: model for congenital generalized lipodystrophy. Genes Dev 12:3182-3194

Ste Marie L, Miura GI, Marsh DJ, Yagaloff K, Palmiter RD 2000 A metabolic defect promotes obesity in mice lacking melanocortin-4 receptors. Proc Natl Acad Sci USA 97:12339-12344

Stephens TW, Basinski M, Bristow PK, Bue-Valleskey JM, Burgett SG, Craft L, Hale J, Hoffmann J, Hsiung HM, Kriauciunas A, MacKellar W, Rosteck PR, Schoner B, Smith D, Tinsley FC, Zhang XY, Heiman M 1995 The role of neuropeptide Y in the antiobesity action of the obese gene product. Nature 377:530-532

Susulic VS, Frederich RC, Lawitts J, Tozzo E, Kahn BB, Harper ME, Himms-Hagen J, Flier JS, Lowell BB 1995 Targeted disruption of the beta 3-adrenergic receptor gene. J Biol Chem 270:29483-29492

Suter KJ, Pohl CR, Wilson ME 2000 Circulating concentrations of nocturnal leptin, growth hormone, and insulin-like growth factor-I increase before the onset of puberty in agonadal male monkeys: potential signals for the initiation of puberty. J Clin Endocrinol Metab $85: 808-814$

Takeda S, Elefteriou F, Levasseur R, Liu X, Zhao L, Parker KL, Armstrong D, Ducy P, Karsenty G 2002 Leptin regulates bone formation via the sympathetic nervous system. Cell 111:305-317

Tansey JT, Sztalryd C, Gruia-Gray J, Roush DL, Zee JV, Gavrilova O, Reitman ML, Deng CX, Li C, Kimmel AR, Londos C 2001 Perilipin ablation results in a lean mouse with aberrant adipocyte lipolysis, enhanced leptin production and resistance to diet induced obesity. Proc Natl Acad Sci USA 98:6494-6499

Trayhurn P 1979 Thermoregulation in the diabetic-obese $(d b / d b)$ mouse. The role of non-shivering thermogenesis in energy balance. Pflugers Arch 380:227-232

Trayhurn P, James WP 1978 Thermoregulation and non-shivering thermogenesis in the genetically obese (ob/ob) mouse. Pflugers Arch 373:189-193

Wang MY, Lee Y, Unger RH 1999 Novel form of lipolysis induced by leptin. J Biol Chem 274:17541-17544

Weigle DS, Bukowski TR, Foster DC, Holderman S, Kramer JM, Lasser G, Lofton-Day CE, Prunkard DE, Raymond C, Kuijper JL 1995 Recombinant ob protein reduces feeding and body weight in the $o b / o b$ mouse. J Clin Invest 96:2065-2070

Yura S, Ogawa Y, Sagawa N, Masuzaki H, Itoh H, Ebihara K, Aizawa-Abe M, Fujii S, Nakao K 2000 Accelerated puberty and late-onset hypothalamic hypogonadism in female transgenic skinny mice overexpressing leptin. J Clin Invest 105:749-755

Zhang Y, Proenca R, Maffei M, Barone M, Leopold L Friedman JM 1994 Positional cloning of the mouse obese gene and its human homologue. Nature 372:425-432 